\title{
A frameshift mutation of the chloroplast mat $K$ coding region is associated with chlorophyll deficiency in the Cryptomeria japonica virescent mutant Wogon-Sugi
}

\author{
Tomonori Hirao • Atsushi Watanabe • \\ Manabu Kurita • Teiji Kondo • Katsuhiko Takata
}

Received: 12 January 2009 / Revised: 21 April 2009 / Accepted: 26 April 2009 / Published online: 18 May 2009

(C) The Author(s) 2009. This article is published with open access at Springerlink.com

\begin{abstract}
Wogon-Sugi has been reported as a cytoplasmically inherited virescent mutant selected from a horticultural variety of Cryptomeria japonica. Although previous studies of plastid structure and inheritance indicated that at least some mutations are encoded by the chloroplast genome, the causative gene responsible for the primary chlorophyll deficiency in Wogon-Sugi, has not been identified. In this study, we identified this gene by genomic sequencing of chloroplast DNA and genetic analysis. Chloroplast DNA sequencing of 16 wild-type and 16 Wogon-Sugi plants showed a 19-bp insertional sequence in the matK coding region in the Wogon-Sugi. This insertion disrupted the mat $\mathrm{K}$ reading frame. Although an indel mutation in the $y c f 1$ and $y c f 2$ coding region was detected in Wogon-Sugi, sequence variations similar to that of Wogon-Sugi were also detected in several
\end{abstract}

Communicated by R. Bock.

Electronic supplementary material The online version of this article (doi:10.1007/s00294-009-0247-9) contains supplementary material, which is available to authorized users.

T. Hirao $\cdot$ A. Watanabe $(\bowtie) \cdot$ M. Kurita $\cdot$ T. Kondo

Forestry and Forest Products Research Institute,

Forest Tree Breeding Center, 3809-1 Ishi,

Juo, Hitachi, Ibaraki 319-1301, Japan

e-mail: nabeatsu@affrc.go.jp

T. Hirao

e-mail: hiratomo@affrc.go.jp

K. Takata

Institute of Wood Technology,

Akita Prefectural University, 11-1 Kaieisaka,

Noshiro, Akita 016-0876, Japan wild-type lines, and they maintained the reading frame. Genetic analysis of the 19 bp insertional mutation in the mat K coding region showed that it was found only in the chlorophyll-deficient sector of 125 full-sibling seedlings. Therefore, the 19-bp insertion in the matK coding region is the most likely candidate at present for a mutation underlying the Wogon-Sugi phenotype.

Keywords Cryptomeria japonica $\cdot$ Wogon-Sugi . Virescent mutant $\cdot$ matK gene $\cdot$ Frameshift mutation

\section{Introduction}

In higher plants, chlorophyll-deficient mutants such as albino, variegated and virescent mutants have been selected and utilized to elucidate the development and function of the chloroplast. The virescent forms of these mutants are phenotypically characterized as having a lag in chlorophyll accumulation in young leaves (Archer and Bonnett 1987; Archer et al. 1987) and have been isolated in a wide range of flowering plants including rice (Iba et al. 1991), barley (Jain 1966), maize (Hopkins and Elfman 1984), cotton (Benedict and Kohel 1970), tobacco (Archer and Bonnett 1987; Archer et al. 1987), and peanut (Benedict and Ketring 1972).

The causative genes or alleles responsible for virescent mutations have recently been described in several plants. For example, virescent or delayed-greening mutants (cue3, cue6, cue8, and clpR1-1) of Arabidopsis are involved in the positive regulation of nuclear gene expression (López-Juez et al. 1998; Vinti et al. 2005; Koussevitzky et al. 2007). Plastid genome (plastome) mutants have been isolated in Hordeum (Rios et al. 2003; Landau et al. 2007), and the corresponding mutations have been characterized at the 
DNA sequence level. In the case of plastome mutants, virescence is inherited in a non-Mendelian fashion, i.e., maternally in the majority of angiosperms and occasionally biparentally.

Cryptomeria japonica (Sugi) is a coniferous tree species that belongs to the group Cupressaceae sensu lato (Kusumi et al. 2000). In C. japonica, a number of mutant varieties show traits such as dwarfism, variegation, and morphological variation in needles and shoots. WogonSugi is a virescent mutant, whose new shoots change color from yellowish-white in spring to normal green in late summer. Ohba et al. (1971) used reciprocal crosses between Wogon-Sugi and wild-type Sugi to demonstrate that the yellowish-white trait of Wogon-Sugi is inherited in a non-Mendelian fashion. In crosses using WogonSugi as the male parent (pollen donor) and wild-type Sugi as the female parent, Wogon-Sugi occurred at a rate of $89.6 \%$, green and white sectors at $7.5 \%$, and the wildtype phenotype at $2.9 \%$. In contrast, controlled crosses using Wogon-Sugi as the female and wild-type Sugi as the male parent resulted in $99 \%$ wild-type and $1 \%$ Wogon-Sugi and chimeric seedlings. This non-Mendelian transmission was maintained even in self-pollinated or backcrossed F1 hybrids derived from the reciprocal crosses. These data suggested paternal inheritance of the plastid genome in $C$. japonica, and provided the initial experimental evidence that at least some types of mutations are encoded by the plastid genome.

Genomic sequencing data provide detailed information on variations and mutations at the nucleotide level. We have already determined the complete nucleotide sequence of the $C$. japonica chloroplast genome using the shotgun sequencing method, and determined that 116 genes are encoded in the genome (Hirao et al. 2008, GenBank accession no. AP009377). Therefore, comparison with wild-type will determine whether there is a specific mutation in the Wogon-Sugi chloroplast genome that is responsible for its phenotype.

The objective of this study was to identify the gene that is mutated in the primary chlorophyll-deficient C. japonica virescent mutant, Wogon-Sugi. To identify candidate genes, we completed nucleotide sequencing of Wogon-Sugi and Yaku-Sugi by PCR-based genome walking. For wild-type we selected Yaku-Sugi, a local race of $C$. japonica in Japan. To identify the specific mutation of the Wogon-Sugi chloroplast genome, comparative analyses were conducted between Wogon-Sugi and wild-type chloroplast genomes and the mutations detected were examined in 16 Wogon-Sugi and 16 wildtype plants. Finally, we examined the relationship between phenotype and genotype using chloroplast DNA markers developed based on the specific mutation of the Wogon-Sugi chloroplast genome.

\section{Materials and methods}

Chloroplast DNA sequencing, sequence assembly, and gene annotation

The virescent mutant of Cryptomeria japonica (WogonSugi) is preserved in 16 individuals in the Forest Products Research Institute, Forest Tree Breeding Center (FFPRIFTBC) in Ibaraki, Japan. To determine the complete sequence of this mutant's chloroplast genome, a WogonSugi sample, W-77, was arbitrarily selected from among 16 individual plants. In addition, one wild-type Yaku-Sugi plant was employed as a comparative sample to detect mutations in the Wogon-Sugi chloroplast genome. The wild-type was collected from a natural $C$. japonica forest ion Yaku Island $\left(30^{\circ} 20^{\prime} \mathrm{N}\right.$ and $\left.130^{\circ} 30^{\prime} \mathrm{E}\right)$ and has been planted in FFPRI-FTBC.

Total cellular DNA of both plant types was prepared by the method of Shiraishi and Watanabe (1995). Approximately $100 \mathrm{mg}$ of leaves was frozen in liquid nitrogen and ground in a homogenizer. The homogenized sample was mixed with $1 \mathrm{ml}$ of CTAB buffer $(100 \mathrm{mM}$ Tris- $\mathrm{HCl}, \mathrm{pH}$ 9.0, 20 mM EDTA, 2\% CTAB (hexadecyltrimethylammonium bromide)) with $0.1 \%$ beta-mercaptoethanol added just prior to use. The mixture was incubated at $65^{\circ} \mathrm{C}$ for $60 \mathrm{~min}$ and centrifuged for $10 \mathrm{~min}$ at $12,000 \times \mathrm{g}$, then $600 \mu \mathrm{l}$ of the supernatant was transferred to a $1.5 \mathrm{ml}$ microcentrifuge tube. The supernatant was mixed twice with phenol/chloroform/isoamyl alcohol (25:24:1) and centrifuged for $10 \mathrm{~min}$ at $12,000 \times g$. DNA was precipitated from the aqueous phase by adding 0.1 volume of $3 \mathrm{M}$ sodium acetate and 2.5 volumes of ethanol. The precipitate was washed twice with $70 \%$ ethanol and dissolved in water. Extracted DNA was further purified using the DNeasy Plant Mini kit (Qiagen).

Complete nucleotide sequencing of the Wogon-Sugi and Yaku-Sugi chloroplast genomes was performed using 345 PCR genome walking primers (http://labglt.nftbc.affrc. go.jp/DNA_analysis_resource/sugi/sugi_cp_primer.html). DNA amplification reactions were carried out in a Gene$\mathrm{Amp}^{\circledR}$ PCR System 9700 (Applied Biosystems) programmed for touchdown PCR from 62 to $57^{\circ} \mathrm{C}$ for each primer. The PCR conditions were as follows: after initial melting at $94^{\circ} \mathrm{C}$ for $1 \mathrm{~min}, 30 \mathrm{~s}$ of denaturation at $94^{\circ} \mathrm{C}$, $1 \mathrm{~min}$ of annealing at $62^{\circ} \mathrm{C}$, and $1 \mathrm{~min}$ of extension at $72^{\circ} \mathrm{C}$ for ten cycles of amplification. At each cycle, the annealing temperature was reduced $0.5^{\circ} \mathrm{C}$, followed by $30 \mathrm{~s}$ of denaturation at $94^{\circ} \mathrm{C}, 1 \mathrm{~min}$ of annealing at $57^{\circ} \mathrm{C}$, and $1 \mathrm{~min}$ of extension at $72^{\circ} \mathrm{C}$ for 20 cycles, followed by a final extension at $72^{\circ} \mathrm{C}$ for $10 \mathrm{~min}$. PCR was performed in a volume of $10 \mu \mathrm{l}$ containing $10 \mathrm{mM}$ Tris- $\mathrm{HCl}, \mathrm{pH} 9.0,50 \mathrm{mM} \mathrm{KCl}$, $1.5 \mathrm{mM} \mathrm{MgCl}_{2}, 0.2 \mathrm{mM}$ each dNTP, $0.2 \mu \mathrm{M}$ each primer, $100 \mathrm{ng}$ genomic DNA and $0.1 \mathrm{U}$ of Taq DNA polymerase 
(Invitrogen). Amplified PCR products were treated with exonuclease and shrimp alkaline phosphatase to remove excess dNTPs and primers. The exonuclease/alkaline phosphatase treatment was performed by mixing $5 \mu \mathrm{l}$ PCR product with $0.2 \mu$ l exonuclease I (10 U/ $\mu \mathrm{l}$; TAKARA), $2.0 \mu \mathrm{l}$ shrimp alkaline phosphatase (1 U/ $\mu \mathrm{l}$; Amersham), $1.0 \mu \mathrm{l}$ SAP $10 \times$ buffer and $1.8 \mu$ deionized water, and then incubating at $37^{\circ} \mathrm{C}$ for $30 \mathrm{~min}$ followed by $75^{\circ} \mathrm{C}$ for $15 \mathrm{~min}$ to inactivate the exonuclease and alkaline phosphatase. Cycle sequencing was performed according to the manufacturer's instructions using BigDye ${ }^{\circledR} 2.0$ Terminator Cycle Sequencing kit (Applied Biosystems). The sequencing primer (3.2 pmol, the same as the PCR primer), $1.0 \mu \mathrm{l}$ ABI Dye Terminator Ready-Reaction sequencing premix and $1.5 \mu \mathrm{l}$ $5 \times$ sequence buffer were added to the template. After a 2-min denaturation step at $96^{\circ} \mathrm{C}$, dye-terminator reactions were incubated at $96^{\circ} \mathrm{C}$ for $15 \mathrm{~s}, 50^{\circ} \mathrm{C}$ for $1 \mathrm{~s}$ and $60^{\circ} \mathrm{C}$ for 4 min for 25 cycles. Excess dye terminators were removed by ethanol precipitation. The extension products were evaporated to dryness under vacuum, resuspended in $\mathrm{Hi}-\mathrm{Di}^{\mathrm{TM}}$ formamide (Applied Biosystems), heated for $2 \mathrm{~min}$ at $94^{\circ} \mathrm{C}$ and loaded onto an ABI PRISM ${ }^{\circledR}$ model 3100 DNA sequencer (Applied Biosystems) according to the manufacturer's directions. For sequence analysis and assembly, we used Sequencher ${ }^{\circledR} 3.1$ software (Gene Codes Corporation). The determined sequence was annotated using DOGMA (Dual Organellar GenoMe Annotator) software (Wyman et al. 2004) after a FASTA-formatted file of the complete chloroplast genome was uploaded to the program's server. The fully annotated chloroplast genome of Wogon-Sugi and one Yaku-Sugi plant was submitted to DDBJ GenBank with the following accession numbers: Wogon-Sugi chloroplast genome, AP010966; Yaku-Sugi chloroplast genome, AP010967. The complete nucleotide sequences of the Wogon-Sugi and Yaku-Sugi chloroplast genomes were aligned using GeneDoc software (Nicholas et al. 1997), and sequence variations between the two genomes were examined for single nucleotide polymorphisms (SNPs), simple sequence repeats (SSRs), and insertions or deletions (indels).

Verification of the mutation in the coding region by DNA sequencing

Mutations in the gene-coding regions, detected from sequence alignment, were examined in 16 wild-type plants and 16 Wogon-Sugi individuals by DNA sequencing. The 16 wild-type plants were 11 local races, AjigasawaSugi, Ooshuku-Sugi, Toudou-Sugi, Makinosaki-Sugi, Honna-Sugi, Mura-Sugi, Kuma-Sugi, Tateyama-Sugi, Itoshiro-Sugi, Ashuu-Sugi, Hachirou-Sugi, plus three individuals from a natural population on Yaku Island and two plus-trees (Nagano 1, Iiyama 16) of Japan. Total cellular DNA of these 16 wild-type plants and 16 WogonSugi individuals was prepared by the method of Shiraishi and Watanabe (1995). Extracted DNA was further purified using the Mag-extractor (Toyobo). DNA sequencing was performed according to the above-described PCR genome walking methods. The sequences determined were aligned using GeneDoc software (Nicholas et al. 1997). Mutations in the nucleotide sequence of the coding region were translated to predict the amino acid sequence, and then the predicted primary structures were compared.

Genetic analysis of the chloroplast genome

A controlled artificial cross was made between a wild-type plant (Yoshiki 1) as the maternal parent and W-77 WogonSugi as the paternal parent. Prior to pollination, the female cones of the wild-type plant were completely enclosed in crossing bags to eliminate foreign pollen contaminants. Mature pollen was collected from Wogon-Sugi male cones for pollination. After pollination, 131 mature F1 seeds were collected, germinated, and the seedlings grown for 1 year in a greenhouse. The phenotype of all 131 seedlings was evaluated for the 20th through the 25th leaves, which were sophomoric leaves and new shoots.

The chloroplast genomes of the 131 seedlings that were characterized for phenotype were examined using a chloroplast DNA marker developed based on a mutation in the Wogon-Sugi chloroplast genome. Total cellular DNA was prepared from each individual by the method of Shiraishi and Watanabe (1995). Extracted DNA was further purified using the Mag-extractor (Toyobo). Fragment analysis was performed by sizing the PCR products. The forward primer used was 5'-AGGTTATTCTTGGGTCCGGGGGTTT-3' and the reverse primer was $5^{\prime}$-ACTAAAATTTCCGTTGG TTCGGAG-3'; these were developed to detect the specific mutation in the mat $\mathrm{K}$ coding region of the WogonSugi chloroplast genome. The forward primer was labeled with HEX fluorescent dye. DNA amplification was carried out in a PTC-200 thermocycler (MJ Research). The PCR conditions were as follows: after initial melting at $94^{\circ} \mathrm{C}$ for $1 \mathrm{~min}, 30 \mathrm{~s}$ of denaturation at $94^{\circ} \mathrm{C}, 30 \mathrm{~s}$ of annealing at $60^{\circ} \mathrm{C}$, and $1 \mathrm{~min} 30 \mathrm{~s}$ of extension at $72^{\circ} \mathrm{C}$ for 30 cycles, followed by a final extension at $72^{\circ} \mathrm{C}$ for $5 \mathrm{~min}$. PCR was performed on samples of the same composition and volume described earlier for PCR genome walking. Amplified PCR products were separated using an ABI PRISM $^{\circledR}$ model 3100 automated DNA sequencer. Labeled fragments were detected and sized using GeneScan ${ }^{\circledR} 350$ $\mathrm{ROX}^{\mathrm{TM}}$ size standards (Applied Biosystems). All genotypes were determined using Genotyper ${ }^{\circledR}$ fragment analysis software version 3.7 genotyping software (Applied Biosystems). 
Table 1 Sequence variations between Wogon-Sugi (mutant) and $\mathrm{Yaku}$-Sugi (wild-type plant) chloroplast genomes
The locations and regions of polymorphic sites between Wogon-Sugi and Yaku-Sugi were documented according to the nucleotide and gene order of the annotated Wogon-Sugi chloroplast genome sequence. Mutations were classified into three types: single nucleotide polymorphism (SNP), simple sequence repeat (SSR), and insertion or deletion (indel). SSR mutations of each chloroplast genome are indicated by repeat motif and repeat number

\begin{tabular}{|c|c|c|c|c|}
\hline $\begin{array}{l}\text { Location in } \\
\text { Wogon-Sugi }\end{array}$ & Region & $\begin{array}{l}\text { Mutation } \\
\text { type }\end{array}$ & Wogon-Sugi & Yaku-Sugi \\
\hline 10876 & rps11-rpl36 spacer & SNP & $\mathrm{T}$ & $\mathrm{G}$ \\
\hline 16344 & $r p l 2$ intron & SSR & $(\mathrm{TA})_{9}$ & $(\mathrm{TA})_{8}$ \\
\hline 20693 & psaJ-trnP spacer & SSR & $(\mathrm{T})_{19}$ & $(\mathrm{~T})_{20}$ \\
\hline 21018 & trn $\mathrm{P}-t r n \mathrm{~W}$ spacer & SNP & A & G \\
\hline 23754 & $p s b \mathrm{~J}-\psi c l p \mathrm{P}$ spacer & SSR & $(\mathrm{T})_{10}$ & $(\mathrm{~T})_{11}$ \\
\hline 23912 & $p s b \mathrm{~J}-\psi$ clpP spacer & SNP & G & $\mathrm{T}$ \\
\hline 24189 & $p s b \mathrm{~J}-\psi c l p \mathrm{P}$ spacer & SSR & $(\mathrm{A})_{11}$ & $(\mathrm{~A})_{12}$ \\
\hline 39584 & chlL-trnH spacer & SSR & $(\mathrm{T})_{11}$ & $(\mathrm{~T})_{10}$ \\
\hline 43948 & mat $\mathrm{K}$ coding region & Indel & $19 \mathrm{bp}$ insertion & - \\
\hline 78669 & atp $\mathrm{I}-a t p \mathrm{H}$ spacer & SSR & $(\mathrm{TA})_{7}$ & $(\mathrm{TA})_{6}$ \\
\hline 82805 & $\operatorname{trn} \mathrm{G}$ intron & SSR & $(\mathrm{A})_{12}$ & $(\mathrm{~A})_{11}$ \\
\hline 86642 & $\operatorname{trn} \mathrm{L}-t r n \mathrm{~F}$ spacer & SSR & $(\mathrm{TA})_{22}$ & $(\mathrm{TA})_{12}$ \\
\hline 92241 & $n d h \mathrm{~A}$ intron & SSR & $(\mathrm{T})_{13}$ & $(\mathrm{~T})_{14}$ \\
\hline 105857 & $\psi y c f 68-r p s 12$ spacer & SNP & $\mathrm{T}$ & $\mathrm{G}$ \\
\hline 105858 & $\psi y c f 68-r p s 12$ spacer & SNP & $\mathrm{C}$ & A \\
\hline 115914 & $y c f 2$ coding region & Indel & $33 \mathrm{bp}$ insertion & - \\
\hline 121743 & $y c f 2-y c f 1$ spacer & SNP & A & G \\
\hline 121981 & $y c f 2-y c f 1$ spacer & SNP & A & $\mathrm{G}$ \\
\hline 128800 & $y c f 1$ coding region & Indel & 66 bp deletion & - \\
\hline 130055 & $\operatorname{trn} \mathrm{L}-c c s \mathrm{~A}$ spacer & Indel & 19 bp deletion & - \\
\hline 131579 & ccsA-pet $\mathrm{A}$ spacer & SNP & $\mathrm{G}$ & $\mathrm{T}$ \\
\hline
\end{tabular}

\section{Results}

General characteristics of Wogon-Sugi and wild-type chloroplast genomes

The size of the Wogon-Sugi chloroplast genome was determined to be $131,804 \mathrm{bp}$, which is slightly larger than the $131,781 \mathrm{bp}$ of wild-type Yaku-Sugi. Both chloroplast genomes encoded a total of 116 genes, 112 of which were single copy and two (trnI-CAU and trnQ-UUG) were duplicated as inverted repeat sequences. Of the 116 genes, there were four ribosomal RNA genes (3.5\%), 30 individual transfer RNA genes (25.9\%), 21 genes encoding large and small ribosomal subunits (18.1\%), four genes encoding DNA-dependent RNA polymerases (3.5\%), 48 genes encoding photosynthesis-related proteins (41.4\%), and nine genes encoding other proteins, including those with unknown functions (7.8\%). Of the 112 single copy genes, 17 contained introns, and three ( $\operatorname{clpP}$, trnT-GGU, and $y c f 68)$ were identified as pseudogenes. In addition, stop codons were found in the mat $\mathrm{K}$ (maturase) coding region of the Wogon-Sugi chloroplast genome.

Sequence variations between the two chloroplast genomes

A total of 21 sequence variations (eight SNPs, nine SSRs, and four indels) were identified from the sequence align- ment of the Wogon-Sugi and Yaku-Sugi chloroplast genomes (Table 1). The eight SNPs, five of the SSRs, and one indel were identified in intergenic spacer regions. The remaining four SSRs were identified in intron regions. The remaining three indels were identified in three gene coding regions: matK (maturase), ycf2 (hypothetical protein RF2) and $y c f 1$ (hypothetical protein RF1).

An insertional mutation in the matK gene of the Wogon-Sugi chloroplast genome causes a frameshift mutation

The insertion or deletion mutations in coding regions mat $\mathrm{K}$, $y c f 2$, and $y c f 1$ were examined in 16 wild-type and 16 Wogon-Sugi plants by DNA sequencing. All three indels of the coding region consisted of duplicated repetitive sequences. The 19-bp insertion in the mat $\mathrm{K}$ coding region was found only in the 16 Wogon-Sugi individuals. This insertion resulted in a reading frameshift after the amino acid residue phenylalanine $(\mathrm{F})$ at the 24 th amino acid residue, introducing a stop codon just after the serine $(\mathrm{S})$ residue at the 39th amino acid residue (Fig. 1). The $y c f 2$ coding region of all 32 plants was classified into four types based on the 33-bp repetitive sequence unit, which is equivalent to an insertion of 11 amino acids (Fig. 2). Four indel variants were identified among the 16 wild-type plants, which are referred to as Types I-IV in Fig. 2. Two wild-type 
Fig. 1 Reading frameshift mutation in the mat $\mathrm{K}$ coding region of the Wogon-Sugi chloroplast genome. The nucleotide and deduced amino acid sequences of part of the mat K gene of Wogon-Sugi and wild-type chloroplast genomes are shown. Blue nucleotides show the insertion sequence in Wogon-Sugi, and red nucleotides show the introduced stop codon

\begin{tabular}{|c|c|c|c|c|c|c|}
\hline Wogon-Sugi & $\begin{array}{c}5 \\
\text { ATGGGTGAAT }\end{array}$ & $\begin{array}{c}15 \\
\text { TCCAAAGAAA }\end{array}$ & $\begin{array}{c}25 \\
\text { TGAAAACAAA }\end{array}$ & $\begin{array}{c}35 \\
\text { CATAAATCTT }\end{array}$ & $\begin{array}{c}45 \\
\text { GGCAACAATT }\end{array}$ & $\begin{array}{c}55 \\
\text { CTTTTTATAT }\end{array}$ \\
\hline \multirow{3}{*}{ Wild type } & $M \quad G \quad E$ & $F \quad Q \quad R$ & $\begin{array}{llll}N & E & N & K\end{array}$ & $\mathrm{H} \quad \mathrm{K} \quad \mathrm{S}$ & $W \quad Q \quad Q$ & $\begin{array}{lll}F & F & L\end{array}$ \\
\hline & ATGGGTGAAT & TCCAAAGAAA & TGAAAACAAA & САTAAATCTT & GGCAACAATT & СТTTTTATAT \\
\hline & $M \quad G \quad E$ & $Q \quad R$ & $\begin{array}{llll}N & E & N & K\end{array}$ & $\mathrm{H} \quad \mathrm{K} \quad \mathrm{S}$ & W $Q Q$ & F $\quad$ L \\
\hline \multirow[b]{3}{*}{ Wogon- } & $\ldots|\ldots|$ & $\ldots|\ldots|$ & $\ldots|\ldots|$ & $\ldots|\ldots|$ & $\ldots|\ldots|$ & .1. \\
\hline & 65 & 75 & 85 & 95 & 105 & 115 \\
\hline & CCGCTTTTTT & ТTTTTATATC & СGСTTTTTTT & TCGGGAAGAT & CTTTACGCAA & TTGCTCAT \\
\hline \multirow{3}{*}{ Wild type } & $P \quad L \quad F$ & $\begin{array}{lll}F & F & I\end{array}$ & $\begin{array}{llll}S & A & F & F\end{array}$ & $S \quad G$ & $\begin{array}{lll}S & \mathrm{~L} & \mathrm{R}\end{array}$ & $\mathrm{N} \quad \mathrm{C} \quad \mathrm{S}$ \\
\hline & CCGCTTTTTT & TT-------- & ---------- & -CGGGAAGAT & СTTTACGCAA & TTGCTCATGA \\
\hline & $P \quad L \quad F$ & $\mathrm{~F}$ & & $\begin{array}{lll}R & E & D\end{array}$ & L $\quad Y \quad A$ & I $\quad$ A $\quad$ H \\
\hline \multirow{3}{*}{ Wogon-Sugi } & $\begin{array}{c}\cdots 1 \ldots . \mid \\
125\end{array}$ & $\begin{array}{c}\ldots 1 \ldots 1 \\
135\end{array}$ & $\begin{array}{c}\ldots|\ldots| \\
145\end{array}$ & $\begin{array}{c}\cdots|\ldots| \\
155\end{array}$ & ${ }_{165}^{\ldots \mid}|\ldots|$ & $\begin{array}{c}\cdots 1 \ldots \\
175\end{array}$ \\
\hline & TCATCATTTA & GATAGATCTG & GTTCCTCCGA & ACCAACGGAA & ATTTTAGTTT & СТАATTTTT \\
\hline & $\begin{array}{lll}S & S & F\end{array}$ & $R * I$ & $\begin{array}{llll}W & F & L & R\end{array}$ & $\mathrm{~T} \quad \mathrm{~N} \quad \mathrm{G}$ & $\begin{array}{lll}N & F & S\end{array}$ & $\mathrm{~F} \quad * \quad \mathrm{~F}$ \\
\hline \multirow{3}{*}{ Wild type } & TCATCATTTA & GATAGATCTG & GTTCCTCCGA & ACCAACGGAA & ATTTTAGTTT & СТААТTTTT \\
\hline & $\begin{array}{llll}\text { D } & \mathrm{H} & \mathrm{H} & \mathrm{L}\end{array}$ & D $\quad \mathrm{R} \quad \mathrm{S}$ & G $\quad S \quad S$ & $\begin{array}{llll}E & P & T & E\end{array}$ & $\begin{array}{lll}\text { I } & \text { L } & \text { V }\end{array}$ & $\begin{array}{lll}S & N & F\end{array}$ \\
\hline & $\begin{array}{c}\cdots|\ldots| \\
185\end{array}$ & $\begin{array}{c}\cdots|\ldots| \\
195\end{array}$ & $\underset{205}{\cdots \mid}$ & & & \\
\hline \multirow[t]{2}{*}{ Wogon-Sugi } & GAGTTTCCTA & ACTGTAAAAC & GTTCAATTCG & & & \\
\hline & E $\quad F \quad P$ & $\mathrm{~N} \quad \mathrm{C} \quad \mathrm{K}$ & $\begin{array}{llll}\mathrm{T} & \mathrm{F} & \mathrm{N} & \mathrm{S}\end{array}$ & & & \\
\hline \multirow[t]{2}{*}{ Wild type } & GAGTTTCCTA & ACTGTAAAAC & GTTCAATTCG & & & \\
\hline & $\begin{array}{llll}L & S & F & L\end{array}$ & T $\quad$ V $\quad \mathrm{K}$ & $\begin{array}{lll}R & S & I\end{array}$ & & & \\
\hline
\end{tabular}

plants had the DNA sequence depicted as Type I, with five copies of the 33-bp sequence repeat. The Type II variants had four copies (two wild-type plants), Type III had three copies (10 plants), and Type IV had two copies (two plants). All 16 Wogon-Sugi plants had the Type I indel. Despite the length variation in the $y c f 2$ coding region, none of the variants caused a change in the reading frame. Similarly, the $y c f 1$ coding region was classified into four types based on the 66-bp repetitive sequence unit found in all 32 plants investigated (Fig. 3): Six plants were classified as Type I, which contained five copies of the 66-bp repeat; six plants were Type II with four copies; three were Type III with three copies, and one plant was Type IV with two copies of the repeat. All Wogon-Sugi plants belonged to Type II. The indel mutations of the $y c f 2$ and $y c f l$ coding regions do not shift the reading frames, but each additional repeat in the $y c f 2$ gene is equivalent to an insertion of 11 amino acids and each additional repeat in the $y c f l$ gene is equivalent to an insertion of 22 amino acids.

The frameshift mutation of the matK coding region of Wogon-Sugi is associated with the primary chlorophyll deficiency of offspring

Of the 131 Wogon-Sugi seedlings produced through controlled crossing, $114(87.0 \%)$ showed yellowish-white leaves (Fig. 4a), six (4.6\%) showed normal green leaves (Fig. 4b), and 11 (8.4\%) showed chimeric leaves (Fig. 4c). The chimeric seedlings exhibited yellowish-white sectors (Fig. 4c-i), normal green sectors (Fig. 4c-ii), and variegated sectors (Fig. 4c-iii).
The results of genetic analysis using chloroplast DNA markers are presented in Table 2. The 114 seedlings that showed yellowish-white leaves had the genotype of the Wogon-Sugi chloroplast genome, namely the 196-bp PCR product (Fig. 5a). The six seedlings that showed normal green leaves had the genotype of the maternal wild-type chloroplast genome, namely the 177-bp PCR product (Fig. 5b). The 11 seedlings that showed chimeric leaves had the genotypes of both the paternal Wogon-Sugi and the maternal wild-type: both the 196- and 177-bp PCR products were present (Fig. 5c-i, ii, iii). For details, in each sector of chimeric seedlings, the yellowish-white sector showed the 196 bp PCR product (Fig. 5c-i), the green sector showed $177 \mathrm{bp}$ PCR product (Fig. 5c-ii), and the variegated sectors showed both 196 and 177 bp PCR products (Fig. 5c-iii). That is, yellowish-white leaves that has the 196-bp PCR product is paternal inheritance of chloroplast genomes, normal green leaves that has the 177-bp PCR product is maternal inheritance, and the variegated sectors that has both 196 and $177 \mathrm{bp}$ PCR products is biparental inheritance.

\section{Discussion}

Previous study of the virescent mutation in Wogon-Sugi was restricted to observation of chloroplast structure and evaluation of the mode of inheritance of the phenotype (Ohba et al. 1971). Although these data provided the initial experimental evidence that at least some types of mutations are encoded by the chloroplast genome, the causative gene 
Fig. 2 Repetitive indel mutations in the $y c f 2$ coding region of Wogon-Sugi and four wild-type chloroplast genomes. The nucleotide and deduced amino acid sequences of part of the $y c f 2$ gene of Types I-IV, and of Wogon-Sugi, showing variation in the number of $66 \mathrm{bp}$ insertions. Colored nucleotides show the 33-bp repetitive units

\begin{tabular}{|c|c|c|c|c|c|c|}
\hline Type I & $\begin{array}{c}5 \\
\text { CAATTGACAA }\end{array}$ & $\begin{array}{c}15 \\
\text { AAGTATGGAA }\end{array}$ & $\begin{array}{c}25 \\
\text { TAAATACTAT }\end{array}$ & $\begin{array}{c}35 \\
\text { TTGGAATTAC }\end{array}$ & $\begin{array}{c}45 \\
\text { AAAAAGTATG }\end{array}$ & $\begin{array}{c}55 \\
\text { GAATAAATAC }\end{array}$ \\
\hline & $\mathrm{Q} \quad \mathrm{L} \quad \mathrm{T}$ & K $\quad \mathrm{V} \quad \mathrm{W}$ & $\begin{array}{llll}N & K & Y & Y\end{array}$ & L $\quad E \quad L$ & Q $\quad K$ & W $\mathrm{N}$ \\
\hline Wogon-Sugi & CAATTGACAA & AAGTATGGAA & TAAATACTAT & TTGGAATTAC & AAAAAGTATG & GAATAAATAC \\
\hline & Q $\quad$ L $\quad T$ & K $\quad \mathrm{V} \quad \mathrm{W}$ & $\mathrm{N} \quad \mathrm{K} \quad \mathrm{Y}$ & L E & Q K & W \\
\hline Type II & CAATTGACAA & AAGTATGGAA & TAAATACTAT & TTGGAATTAC & AAAAAGTATG & GAATAAATAC \\
\hline & Q $\quad \mathrm{L} \quad \mathrm{T}$ & $\begin{array}{lll}K & \mathrm{~V} & \mathrm{~W}\end{array}$ & $\begin{array}{llll}N & K & Y & Y\end{array}$ & L $\quad E \quad L$ & $\mathrm{~K}$ & $\begin{array}{lll}W & N & K\end{array}$ \\
\hline Type III & CAATTGACAA & AAGTATGGAA & TAAATACTAT & TTGGAATTAC & AAAAAGTATG & GAATAAATAC \\
\hline & Q $\quad \mathrm{L} \quad \mathrm{T}$ & $\begin{array}{lll}K & \mathrm{~V} & \mathrm{~W}\end{array}$ & $\begin{array}{llll}N & K & Y & Y\end{array}$ & L E L & V & $\mathrm{N} \quad \mathrm{K}$ \\
\hline Type IV & CAATTGACAA & AAGTATGGAA & TAAATACTAT & TTGGAATTAC & AAAAAGTATG & GAATAAATAC \\
\hline & $\begin{array}{c}Q \quad L \quad T \\
\cdots \\
\cdots \\
65\end{array}$ & 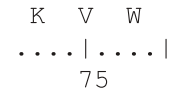 & \begin{tabular}{cccc}
$N$ & $K$ & $Y$ & $Y$ \\
$\cdots$ & $\cdots$ & $\ldots$ & $\ldots$ \\
\multicolumn{4}{c}{85}
\end{tabular} & $\begin{array}{c}L \quad E \quad L \\
\cdots \\
\cdots \\
95\end{array}$ & $\begin{array}{c}Q \quad \mathrm{~K} \quad \mathrm{~V} \\
\ldots\left|{ }^{\prime} \ldots\right| \\
105\end{array}$ & $\begin{array}{ccc}W & N \quad K & Y \\
\cdots & . \mid & \ldots\end{array}$ \\
\hline Type I & TATTTGGAAT & TACAAAAAGT & ATGGAATAAA & TACTATTTGG & AATTACAAAA & AGTATGGAAT \\
\hline Wogon-Sugi & $\begin{array}{ccc}\text { Y } & \text { L } & E \\
\text { TATTTGGAAT }\end{array}$ & $\begin{array}{c}\mathrm{L} \\
\text { TACAAAAAGT }\end{array}$ & $\begin{array}{lllr}V & W & N & K \\
& \text { ATGGAATAAA }\end{array}$ & $\begin{array}{c}\text { Y } \\
\text { Y } \\
\text { TACTATTTGG }\end{array}$ & $\begin{array}{c}E \quad L \quad Q \\
\text { AATTACAAAA }\end{array}$ & $\begin{array}{llll}K & V & W & N \\
\text { AGTATGGAAT }\end{array}$ \\
\hline Type II & $\begin{array}{ccc}\text { Y } & \text { L } & \text { E } \\
\text { TATTTGGAAT }\end{array}$ & $\begin{array}{ccc}\mathrm{L} & \mathrm{Q} & \mathrm{K} \\
\text { TACAAAAAGT }\end{array}$ & $\begin{array}{lllr}V & W & N & K \\
\text { ATGGAATAAA }\end{array}$ & $\begin{array}{ccc}\text { Y } & \text { Y } & \text { L } \\
\text { TACTATTTGG }\end{array}$ & $\begin{array}{c}\text { E I } \\
\text { AATTACAAAA }\end{array}$ & $\begin{array}{llll}K & V & W & N \\
\text { AGTATGGAAT }\end{array}$ \\
\hline Type III & $\begin{array}{ccc}\text { Y } & \text { L } & E \\
\text { TATTTGGAAT }\end{array}$ & $\begin{array}{ccc}\mathrm{L} & \mathrm{Q} & \mathrm{K} \\
\text { TACAAAAAGT }\end{array}$ & $\begin{array}{lllr}V & W & N & K \\
\text { ATGGAATAAA }\end{array}$ & $\begin{array}{c}\text { Y } \\
\text { Y } \\
\text { TACTATTTGG }\end{array}$ & $\begin{array}{c}E \quad L \quad Q \\
\text { AATTACAAAA }\end{array}$ & $\begin{array}{llll}\text { K } & V & W & N \\
\text { AGTATGGAAT }\end{array}$ \\
\hline Type IV & $\begin{array}{ccc}\text { Y } & \text { L } & \text { E } \\
\text { TATTTGGAAT }\end{array}$ & $\begin{array}{ccc}L & Q & K \\
\text { TACAAAAAGT }\end{array}$ & $\begin{array}{lllr}V & W & N & K \\
\text { ATGGAATAAA }\end{array}$ & $\begin{array}{c}\text { Y } \\
\text { Y } \\
\text { TACTATTTGG }\end{array}$ & $\begin{array}{cll}E & \mathrm{~L} & \mathrm{Q} \\
\text { AATT------ }\end{array}$ & 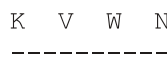 \\
\hline Type I & $\begin{array}{c}\text { Y L E } \\
\ldots|\ldots| \\
125 \\
\text { AAATACTATT }\end{array}$ & $\begin{array}{c}\text { L } Q \text { K } \\
\ldots \ldots|\ldots| \\
135 \\
\text { TGGAATTACA }\end{array}$ & $\begin{array}{l}\mathrm{V} \quad \mathrm{W} \quad \mathrm{N} \\
\ldots \ldots \mid \ldots \\
145 \\
\text { AAAAGTATGG }\end{array}$ & $\begin{array}{c}Y \quad Y \quad L \\
\ldots|\ldots| \\
155 \\
\text { AATAAATACT }\end{array}$ & $\begin{array}{l}\text { E } \\
\ldots \ldots|\ldots| \\
165 \\
\text { ATTTGGAATT }\end{array}$ & $\begin{array}{c}\ldots|\ldots| \\
175 \\
\text { ACAAAAAGTA }\end{array}$ \\
\hline Wogon-Sugi & $\begin{array}{ccc}\text { K } & \text { Y } & \text { Y } \\
\text { AAATACTATT }\end{array}$ & $\begin{array}{ccc}L & \text { E } & \text { L } \\
\text { TGGAATTACA }\end{array}$ & $\begin{array}{llll}Q & K & V & W \\
\text { AAAAAGTATGG }\end{array}$ & $\begin{array}{ccc}\mathrm{N} & \mathrm{K} & \mathrm{Y} \\
\text { AATAAAATACT }\end{array}$ & $\begin{array}{ccc}Y & L & \text { E } \\
\text { ATTTGGAATT }\end{array}$ & $\begin{array}{llll}L & Q & K & V \\
\text { ACAAAAAGTA }\end{array}$ \\
\hline Type II & $\begin{array}{ccc}\text { K } & \text { Y } & \text { Y } \\
\text { AAATACTATT }\end{array}$ & $\begin{array}{ccc}\text { L } & \text { E } & \text { L } \\
\text { TGGAATTACA }\end{array}$ & $\begin{array}{llll}Q & K & V & W \\
\text { AAAAAGTATGG }\end{array}$ & $\begin{array}{ccc}\mathrm{N} & \mathrm{K} & \mathrm{Y} \\
\text { AATAAATACT }\end{array}$ & $\begin{array}{ccc}\text { Y } & \text { L } & \text { E } \\
\text { ATTTGGAATT }\end{array}$ & 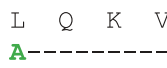 \\
\hline Type III & $\begin{array}{ccc}K & Y & Y \\
\text { AATACTATT }\end{array}$ & $\begin{array}{ccc}\mathrm{L} & \mathrm{E} & \mathrm{L} \\
\text { TGGAATT--_- }\end{array}$ & $\begin{array}{lllll}Q & K & V & W\end{array}$ & $\begin{array}{lll}N & K & Y\end{array}$ & Y L E & \\
\hline Type IV & $\begin{array}{ccc}K & Y & Y \\
--------\end{array}$ & L E & & & & \\
\hline Type I & $\begin{array}{c}\ldots|\ldots| \\
185 \\
\text { TGGAATAAAT }\end{array}$ & $\begin{array}{c}\ldots|\ldots| \\
195 \\
\text { АСTATTTGGA }\end{array}$ & $\begin{array}{c}\cdots|\ldots| \\
205 \\
\text { АTTCAATTTT }\end{array}$ & $\begin{array}{c}\ldots|\ldots| \\
215 \\
\text { GAATTACGAA }\end{array}$ & $\begin{array}{c}\ldots \ldots|\ldots| \\
225 \\
\text { AAATATTAAA }\end{array}$ & $\begin{array}{c}\ldots .|\cdots| \\
235 \\
\text { TAGAATCTAT }\end{array}$ \\
\hline Wogon-Sugi & $\begin{array}{ccc}W & N & K \\
\text { TGGAATAAAT }\end{array}$ & $\begin{array}{ccc}\text { Y } & \text { Y } \\
\text { ACTATTTGGA }\end{array}$ & $\begin{array}{llll}\text { E } & \text { F } & \text { N } & \text { F } \\
\text { ATTCAATTTT }\end{array}$ & $\begin{array}{ccc}E & L & R \\
\text { GAATTACGAA }\end{array}$ & $\begin{array}{c}\text { K I I } \\
\text { AAATATTAAA }\end{array}$ & $\begin{array}{lccc}N & R & I & Y \\
\text { TAGAATCTAT }\end{array}$ \\
\hline Type II & 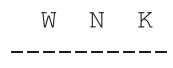 & $\begin{array}{lll}Y & Y & L\end{array}$ & $\begin{array}{lcrr}\text { E } & \text { F } & \text { N } & \text { F } \\
- \text {--CAATTTT }\end{array}$ & $\begin{array}{ccc}E & L & R \\
\text { GAATTACGAA }\end{array}$ & $\begin{array}{c}\text { K I I } \\
\text { AAATATTAAA }\end{array}$ & $\begin{array}{lccc}N & R & \text { I } & \text { Y } \\
\text { TAGAATCTAT }\end{array}$ \\
\hline Type & -- & -- & $\begin{array}{rr}F \quad N \quad F \\
--- \text { CAATTTT }\end{array}$ & $\begin{array}{ccc}E & L & R \\
\text { GAATTACGAA }\end{array}$ & $\begin{array}{c}\text { K I I } \\
\text { AAATATTAAA }\end{array}$ & $\begin{array}{lrrr}N & R & I & Y \\
\text { TAGAATCTAT }\end{array}$ \\
\hline ype IV & -- & -- & $\begin{array}{rr}F & N \quad F \\
--- \text { CAATTTT }\end{array}$ & $\begin{array}{ccc}E & L & R \\
\text { GAATTACGAA }\end{array}$ & $\begin{array}{c}\text { K I I } \\
\text { AAATATTAAA }\end{array}$ & $\begin{array}{lccc}N & R & I & Y \\
\text { TAGAATCTAT }\end{array}$ \\
\hline & & & $\mathrm{F} \quad \mathrm{N}$ & $E \quad L \quad R$ & K I & $\mathrm{N} \quad \mathrm{R} \quad \mathrm{I}$ \\
\hline
\end{tabular}

responsible for the yellowish-white (chlorophyll-deficient) leaves of Wogon-Sugi was not identified. The present results, which used the chloroplast genomic sequence and genetic analysis using chloroplast DNA markers, indicated that a frameshift mutation in the mat $\mathrm{K}$ coding region is associated with the primary chlorophyll-deficiency traits of Wogon-Sugi.

Although comparative analysis of Wogon-Sugi and Yaku-Sugi identified 21 sequence polymorphisms (including eight SNPs, nine SSRs, and four indels), only three of the polymorphisms were located in the coding region; these three polymorphisms were indels. Therefore, these variations in the mat $\mathrm{K}, y c f 2$, and $y c f 1$ coding regions were considered candidates for the mutation responsible for the Wogon-Sugi phenotype. In Wogon-Sugi individuals, a 19-bp insertional mutation was found in the matK coding region. This insertion disrupts the mat $\mathrm{K}$ reading frame. On the other hand, the indels of $y c f 2$ and $y c f 1$, which were respectively 33 and $66 \mathrm{bp}$ repetitive sequence units, were found in both Wogon-Sugi and wild-type chloroplast genomes. Therefore, the insertional sequence in the matK coding region must be the mutation specific to the WogonSugi chloroplast genome and the one responsible for the developmental chlorophyll deficiency, because the $19 \mathrm{bp}$ insertion in the mat $\mathrm{K}$ gene leads to a reading frameshift after the 24th residue, phenylalanine, and results in a stop codon after the 39th residue in the Wogon-Sugi mutant.

The type of frameshift mutation in the matK coding region has not been reported in other plant species. On the other hand, a similar indel mutation within $y c f 1$ and $y c f 2$ has been reported in intraspecies comparisons of Oenothera hookeri (Blasko et al. 1988) and between plants from 
Fig. 3 Repetitive indel mutations in the $y c f 1$ coding region of Wogon-Sugi and four wild-type chloroplast genomes. The nucleotide and deduced amino acid sequences of part of the $y c f 1$ gene of Types I-IV, and of Wogon-Sugi, showing variation in the number of $198 \mathrm{bp}$ insertions. Colored nucleotides show the 66-bp repetitive units
Type I

Type II

Wogon-Sugi

Type III

Type IV

Type I

Type II

Wogon-Sugi

Type III

Type IV

Type I

Type II

Wogon-Sugi

Type III

Type IV

Type I

Type II

Wogon-Sugi

Type III

Type IV

Type I

Type II

Wogon-Sugi

Type III

Type IV

Type I

Type II

Wogon-Sugi

Type III

Type IV

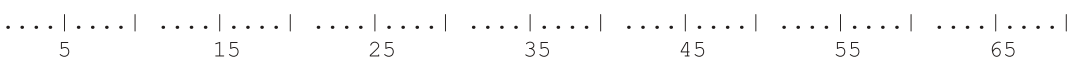
TTTAGGGAGA AACTTAGAAA ATTTCTAACG GAAAGTAGAG ATTCTCTTCC AAAATTGATA AGTTCTTTTA $\begin{array}{lllllllllllllllllllllllll}F & R & E & K & L & R & K & F & L & T & E & S & R & D & S & L & P & K & L & I & S & S & F\end{array}$ TTTAGGGAGA AACTTAGAAA ATTTCTAACG GAAAGTAGAG ATTCTCTTCC AAAATTGATA AGTTCTTTTA TTAGGGAGA AACTTAGAAA ATTTCTAACG GAAAGTAGAG ATTCTCTTCC AAAATTGATA AGTTCTTTTA $\begin{array}{lllllllllllllllllllllllll}F & R & E & K & L & R & K & F & L & T & E & S & R & D & S & L & P & K & L & I & S & S & F\end{array}$ TTTAGGGAGA AACTTAGAAA ATTTCTAACG GAAAGTAGAG ATTCTCTTCC AAAATTGATA AGTTCTTTTA $\begin{array}{lllllllllllllllllllllllllll} & F & R & E & K & L & R & K & F & L & T & E & S & R & D & S & L & P & K & L & I & S & S & F\end{array}$ TTTAGGGAGA AACTTAGAAA ATTTCTAACG GAAAGTAGAG ATTCTCTTCC AAAATTGATA AGTTCTTTTA $\begin{array}{llllllllllllllllllllllllll} & F & R & E & K & L & R & K & F & L & T & E & S & R & D & S & L & P & K & L & I & S & S & F\end{array}$

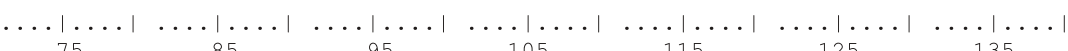

GGGAGAAACT TAGAAAATTT CTAACGGAAA GTAGAGATTC TCTTCCAAAA TTGATAAGTT CTTTTAGGGA $\begin{array}{lllllllllllllllllllllllll}R & E & K & L & R & K & F & L & T & E & S & R & D & S & L & P & K & L & I & S & S & F & R\end{array}$ GGGAGAAACT TAGAAAATTT CTAACGGAAA GTAGAGATTC TCTTCCAAAA TTGATAAGTT CTTTTAGGGA

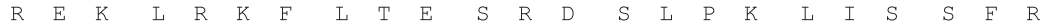
GGGAGAAACT TAGAAAATTT CTAACGGAAA GTAGAGATTC TCTTCCAAAA TTGATAAGTT CTTTTAGGGA $\begin{array}{llllllllllllllllllllllllll}R & E & K & L & R & K & F & L & T & E & S & R & D & S & L & P & K & L & I & S & S & F & R\end{array}$ GGGAGAAACT TAGAAAATTT CTAACGGAAA GTAGAGATTC TCTTCCAAAA TTGATAAGTT CTTTTAGGGA $\begin{array}{lllllllllllllllllllllllll}R & E & K & L & R & K & F & L & T & E & S & R & D & S & L & P & K & L & I & S & S & F & R\end{array}$ GGGAGAAACT TAGAAAATTT CTAACGGAAA GTAGAGATTC TCTTCCAAAA TTGATAAGTT CTTTTAGGGA $\begin{array}{llllllllllllllllllllllll}R & E & K & L & R & K & F & L & T & E & S & R & D & S & L & P & K & L & I & S & S & F & R\end{array}$

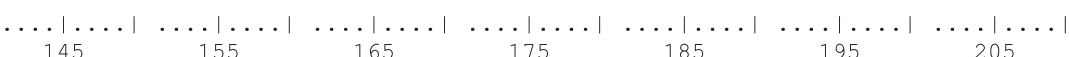
GAAACTTAGA AAATTTCTAA CGGAAAGTAG AGATTCTCTT CCAAAATTGA TAAGTTCTTT TAGGGAGAAA $\begin{array}{lllllllllllllllllllllllll}E & K & L & R & K & F & L & T & E & S & R & D & S & L & P & K & L & I & S & S & F & R & E & K\end{array}$ GAAACTTAGA AAATTTCTAA CGGAAAGTAG AGATTCTCTT CCAAAATTGA TAAGTTCTTT TAGGGAGAAA

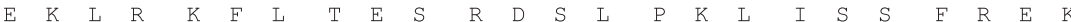
GAAACTTAGA AAATTTCTAA CGGAAAGTAG AGATTCTCTT CCAAAATTGA TAAGTTCTTT TAGGGAGAAA

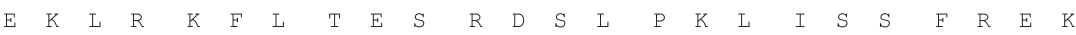
GAAACTTAGA AAATTTCTAA CGGAAAGTAG AGATTCTCTT CCAAAATTGA TAAGTTCTTT TAGGGAGAAA

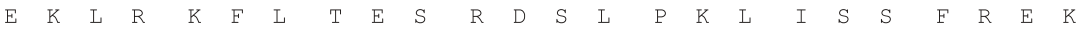

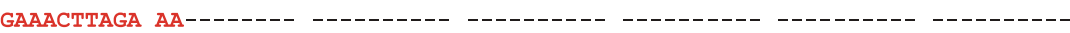
E $\quad$ K

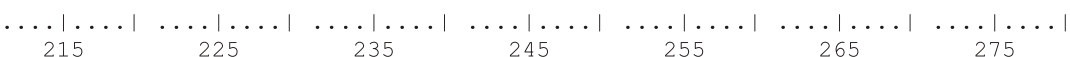

CTTAGAAAAT TTCTAACGGA AAGTAGAGAT TCTCTTCCAA AATTGATAAG TTCTTTTAGG GAGAAACTTA $\begin{array}{llllllllllllllllllllllllll}L & R & K & F & L & T & E & S & R & D & S & L & P & K & L & I & S & S & F & R & E & K & L\end{array}$ CTTAGAAAAT TTCTAACGGA AAGTAGAGAT TCTCTTCCAA AATTGATAAG TTCTTTTAGG GAGAAACTTA $\begin{array}{llllllllllllllllllllllll}\text { L } & R & K & F & \text { L } & \text { T } & \text { E } & \text { S } & \text { R } & \text { D } & \text { S } & \text { L } & \text { P } & \text { K } & \text { L } & \text { I } & \text { S } & \text { S } & \text { F } & \text { R } & \text { E } & \text { K } & \text { L }\end{array}$ CTTAGAAAAT TTCTAACGGA AAGTAGAGAT TCTCTTCCAA AATTGATAAG TTCTTTTAGG GAGAAACTTA $\begin{array}{lllllllllllllllllllllllllll}L & R & K & F & L & T & E & S & R & D & S & L & P & K & L & I & S & S & F & R & E & K & L \\ & \end{array}$$$
\text { L } \quad \text { R }
$$

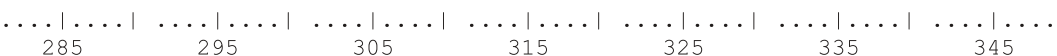
GAAAATTTCT AACGGAAAGT AGAGATTCTC TTCCAAAATT GATAAGTTCT TTTAGGGAGA AACTTAGAAA $\begin{array}{lllllllllllllllllllllllll}R & K & F & L & T & E & S & R & D & S & L & P & K & L & I & S & S & F & R & E & K & L & R\end{array}$ GAAA- - - - $\mathrm{R}$

GAA

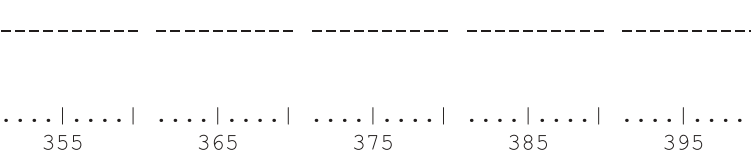

GTTTCTAACG GAAAgTAGA ATTCTCTTCT AAAAAATGGA ATCATAAGAA $\begin{array}{lllllllllllllllllllllll}K & F & L & T & E & S & R & D & S & L & L & K & N & G & I & I & R\end{array}$ GTTTCTAACG GAAAgTAGA ATTCTCTTCT AAAAAATGGA ATCATAAGAA $\begin{array}{lllllllllllllllllllll}K & \text { F } & \text { L } & \text { T } & \text { E } & \text { S } & \text { R } & \text { D } & \text { S } & \text { L } & \text { L } & \text { K } & \text { N } & \text { G } & \text { I } & \text { I } & R\end{array}$ GTTTCTAACG GAAAGTAGAG ATTCTCTTCT AAAAAATGGA ATCATAAGAA $\begin{array}{llllllllllllllllll}K & F & L & T & E & S & R & D & S & L & L & K & N & G & I & I & R\end{array}$ GTTTCTAACG GAAAGTAGAG ATTCTCTTCT AAAAAATGGA ATCATAAGAA $\begin{array}{llllllllllllllllll}K & F & L & T & E & S & R & D & S & L & L & K & N & G & & I & I & R\end{array}$ GTTTCTAACG GAAAGTAGA ATTCTCTTCT AAAAAATGGA ATCATAAGAA $\begin{array}{llllllllllllllllll}K & F & L & T & E & S & R & D & S & L & L & K & N & G & I & I & R\end{array}$ 
Fig. 4 The phenotypes obtained from an artificial cross between Wogon-Sugi (paternal parent) and wild-type (maternal parent). a Wogon-Sugi type with yellowish-white leaves. b Wild-type with normal green leaves. c Chimeric type with yellowishwhite sectors and normal green sectors. In the chimeric type, the yellowish-white sector, the green sector, and the variegated sectors are shown as $\mathbf{c - i}, \mathbf{c}-\mathbf{i i}$, and c-iii, respectively. Red arrows show the sample used for genetic analysis
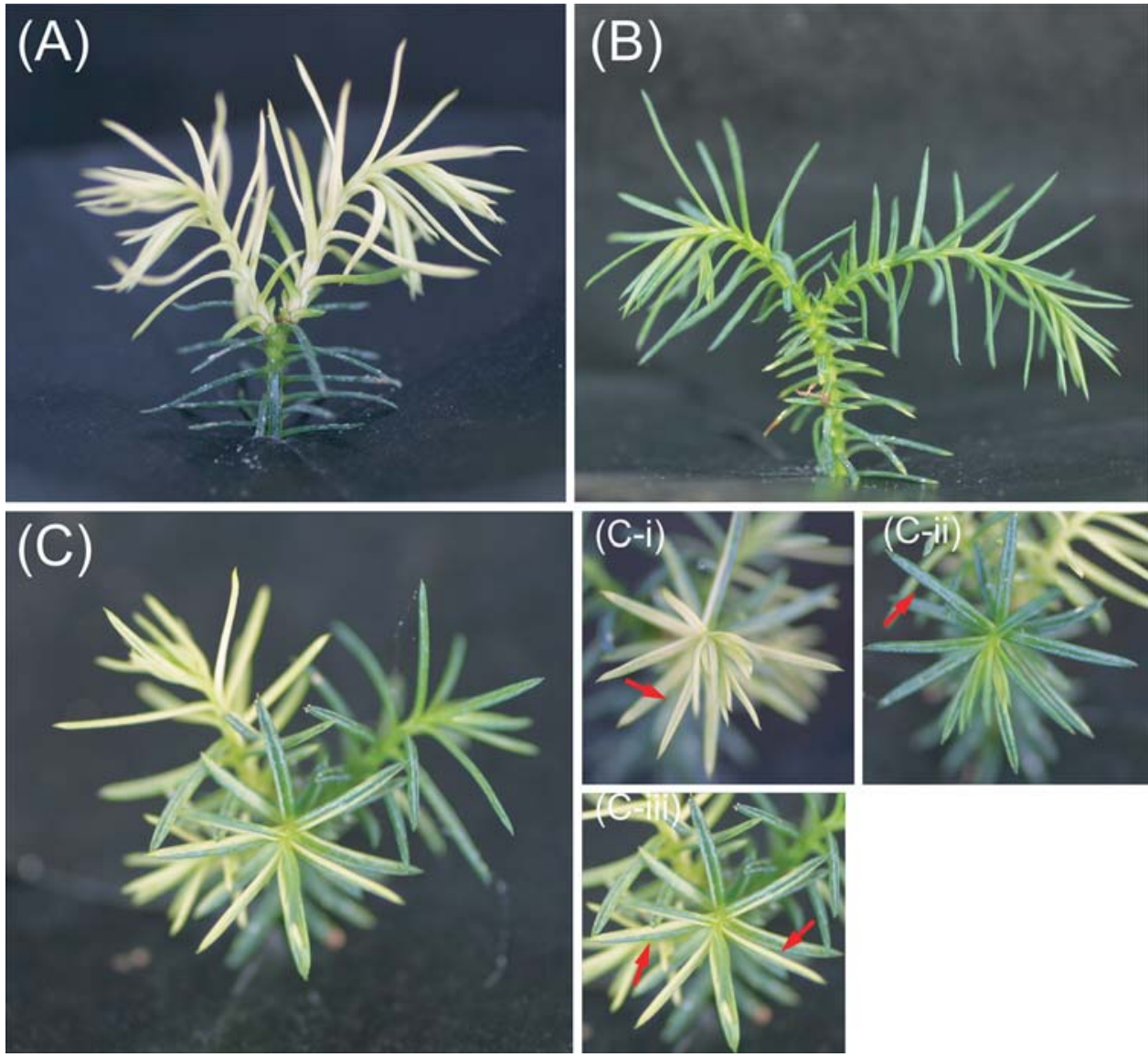

Table 2 Results of genetic analysis in 131 offspring using a chloroplast DNA marker

\begin{tabular}{lllll}
\hline & \multicolumn{2}{l}{ Inheritance pattern $^{\mathrm{a}}$} & & \\
\cline { 2 - 5 } & Wogon-Sugi type (Paternal) & Wild-type type (Maternal) & Chimeric type (Biparental) & Total \\
\hline Number of observed seedlings ${ }^{\mathrm{b}}$ & 114 & 6 & 11 & 131 \\
Rate $(\%)$ & 87.0 & 4.6 & 8.4 & 100 \\
\hline
\end{tabular}

${ }^{a}$ The 131 offspring were obtained by an artificial cross between wild-type (Yoshiki 1; maternal parent) and Wogon-Sugi (paternal parent)

b The chloroplast genomes of each of the 131 offspring were genotyped based on the length variation of PCR product (Fig. 5)

subsection Oenothera (Nimzyk et al. 1993; Greiner et al. 2008), which were also changes in a repetitive sequence without a reading frameshift. One point to consider is the possibility that the Wogon-Sugi chloroplast genome has point mutations that prevent proper annealing of primers in a PCR reaction, and a nuclear paralog with a better fit is amplified instead. Consequently, we conducted the PCRRFLP analysis as a supplementary analysis, namely detection of longer chloroplast regions, including matK from Wogon-Sugi total DNA with two different primer combinations. The results showed a clear size differentiation between Wogon-Sugi and wild-type (supplementary data $\mathrm{S} 1$ ); the longer regions including matK (with the insertional mutation) were only observed in Wogon-Sugi, and not for the nuclear paralog.
The $m a t \mathrm{~K}$ gene, which is encoded in the $\operatorname{trn\mathrm {K}}$ intron of the chloroplast genome, is utilized in systematic studies because of its high mutation rate and resolution (Shaw et al. 2005). Furthermore, indels are frequent in mat K, though they primarily occur in multiples of three, maintaining the reading frame (Barthet and Hilu 2007). We conducted an additional comparative analysis with other five plant species (three angiosperm species and two gymnosperm species) to examine the conservation of the mat $\mathrm{K}$ amino-acid sequence in $C$. japonica, especially in the location of the insertional mutation of Wogon-Sugi. The results indicated that the mutation point of Wogon-Sugi after the amino acid residue phenylalanine $(\mathrm{F})$ at the 24th amino acid residue is highly conserved between $C$. japonica generally and other five plants (supplementary data S2). Thus, the location of 
Fig. 5 Fluorescently labeled PCR products from the three seedling types of Fig. 4. The expected PCR product size of Wogon-Sugi type and wild-type (Yoshiki 1) is $196 \mathrm{bp}$ and 177 bp, respectively. a Yellowish-white leaves with the Wogon-Sugi type matK indel. b Normal green leaves with the wild-type mat $\mathrm{K}$ indel. c-i Yellowish-white sector of chimeric seedling with the Wogon-Sugi type matK indel; c-ii normal green sector of chimeric seedling with the wildtype mat $\mathrm{K}$ indel; $\mathbf{c}$-iii variegated sector of chimeric seedling with the Wogon-Sugi type matK indel and the wild-type matK indel. The rightmost peak of each group corresponds to the expected PCR product (196 bp and $177 \mathrm{bp})$. On the left, peaks corresponding to slippage of the Taq polymerase are visible (195 bp and $176 \mathrm{bp}$ )

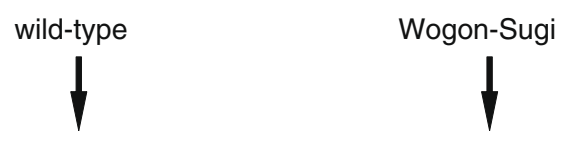

(A)

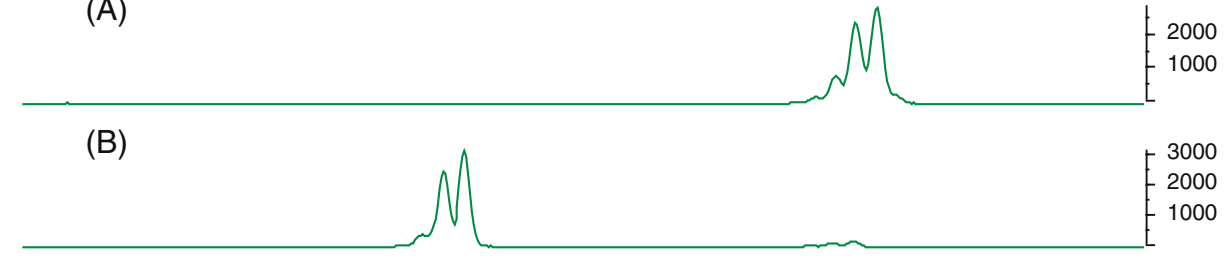

(C-i)

(C-iii)

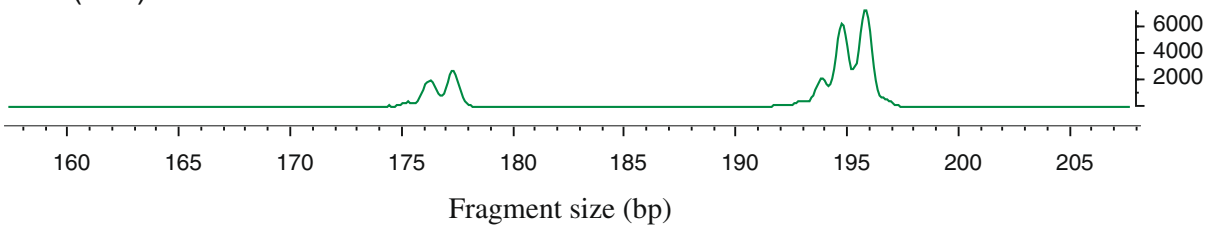

is the most likely candidate for a polymorphism underlying the Wogon-Sugi phenotype.

The mat $\mathrm{K}$ gene is assumed to be the splicing factor for group II introns in the chloroplast genome (Neuhaus and Link 1987). Although the maturase function of MatK is not clearly understood, in white barley its maturase-like function is indirectly associated with the mutant albostrians, which has a chloroplast ribosome deficiency that results in the loss of all chloroplast-encoded proteins including MatK (for a review, see Hess et al. 1994a; Schmitz-Linneweber and Barkan 2007). The group II intron-containing precursor transcripts of $\operatorname{trnK}$, $\operatorname{trn} \mathrm{A}, \operatorname{trn} \mathrm{I}, \operatorname{rps} 12, r p l 2$, and $\operatorname{atpF}$ remain unspliced in albostrians plastids (Hess et al. 1994b; Hübschmann et al. 1996; Vogel et al. 1997, 1999). Barthet and Hilu (2007) suggested that MatK has an essential function as a posttranscriptional splicing factor at a particular developmental stage, and thus its function indirectly contributes to photosynthetic competency of the chloroplast.

In the primary yellowish-white sector of new shoots in Wogon-Sugi plants, there is the possibility that mat $\mathrm{K}$ of the mutated version lacks or has insufficient function as a result of the frameshift mutation, and that genes containing group II introns might not be spliced. However, there are several unclear aspects about the frameshift mutation of matK in the Wogon-Sugi plastid genome. For example, it is not a lethal mutation, and the yellowish-white traits of WogonSugi often change to normal green in late summer (supplementary data S3). Furthermore, once the yellowish-white leaves change to green, their color is stable. $C$. japonica is a 
perennial plant and the virescence of new shoots in WogonSugi is observed only early in development, even though later the shoot plastids still have the Wogon-Sugi genotype.

Regarding the behavior of the virescent mutation in Wogon-Sugi, one possibility is that a nuclear gene might be associated with the splicing of genes having the group II intron in the plastid genome. Leon et al. (1998) reviewed the range of mutants known to have altered chloroplast development and concluded that almost every step of plastid development depends on the direct action of nuclearencoded genes. In fact, in maize (Zea mays) chloroplasts, genetic analyses have shown that nuclear-encoded proteins are associated with the splicing of at least 10 of the 17 group II introns (Jenkins et al. 1997; Jenkins and Barkan 2001; Till et al. 2001; Ostheimer et al. 2003; Ostersetzer et al. 2005). Therefore, we hypothesize that a nuclearencoded splicing factor is recruited as an alternative splicing factor for the chloroplast during the greening of virescent Wogon-Sugi shoots. To test this hypothesis, more detailed analysis is required at the transcriptional and posttranscriptional levels to establish whether the Wogon-Sugi behavior originates with the frameshift mutation of the mat $\mathrm{K}$ gene, and to determine its association with a nuclearencoded splicing factor.

Acknowledgments We thank Dr. Shohab Youssefian (Akita Prefectural University) for helpful discussions, comments and advice, and Dr. Barry Jaquish (BC Ministry of Forests and Range, Victoria) for helpful comments and advice.

Open Access This article is distributed under the terms of the Creative Commons Attribution Noncommercial License which permits any noncommercial use, distribution, and reproduction in any medium, provided the original author(s) and source are credited.

\section{References}

Archer EK, Bonnett HT (1987) Characterization of a virescent chloroplast mutant of tobacco. Plant Physiol 83:920-925

Archer EK, Hakansson G, Bonnett HT (1987) The phenotype of a virescent chloroplast mutation in Tobacco is associated with the absence of a $37.5 \mathrm{kD}$ thylakoid polypeptide. Plant Physiol 83:926-932

Barthet MM, Hilu KW (2007) Expression of matK: functional and evolutionary implications. Am J Bot 94:1402-1412

Benedict CR, Ketring DL (1972) Nuclear gene affecting greening in virescent peanut leaves. Plant Physiol 49:972-976

Benedict CR, Kohel RJ (1970) Photosynthetic rate of a virescent cotton mutant lacking chloroplast grana. Plant Physiol 45:519-521

Blasko K, Kaplan SA, Higgins KG, Wolfson R, Sears BB (1988) Variation in copy number of a 24-base pair tandem repeat in the chloroplast DNA of Oenothera hookeri strain Johansen. Curr Genet 14:287-292

Greiner S, Wang X, Rauwolf U, Silber MV, Mayer K, Meurer J, Haberer G, Herrmann RG (2008) The complete nucleotide sequences of the five genetically distinct plastid genomes of Oenothera, subsection Oenothera: I. Sequence evaluation and plastome evolution. Nucleic Acids Res 36:2366-2378
Hess WR, Hübschmann T, Börner T (1994a) Ribosome-deficient plastids of albostrians barley: extreme representatives of non-photosynthetic plastid. Endocytobios Cell Res 10:65-80

Hess WR, Hoch B, Zeltz P, Hübschmann T, Kössel H, Börner T (1994b) Inefficient rpl2 splicing in barley mutants with ribosomedeficient plastids. Plant Cell 6:1455-1465

Hirao T, Watanabe A, Kurita M, Kondo T, Takata K (2008) Complete nucleotide sequence of the Cryptomeria japonica D. Don. chloroplast genome and comparative chloroplast genomics: diversified genomic structure of coniferous species. BMC Plant Biol 8:70

Hopkins WG, Elfman B (1984) Temperature-induced chloroplast ribosome deficiency in virescent maize. J Hered 75:207-211

Hübschmann T, Hess WR, Börner T (1996) Impaired splicing of the rps12 transcript in ribosome-deficient plastids. Plant Mol Biol 30:109-123

Iba K, Takamiya K, Toh Y, Satoh H, Nishimura M (1991) Formation of functionally active chloroplasts is determined at a limited stage of leaf development in virescent mutants of rice. Dev Genet 12:342-348

Jain ML (1966) Biochemical definition of yellow-virescent and lightgreen suppressor mutations in barley. Genetics 54:813-818

Jenkins B, Barkan A (2001) Recruitment of a peptidyl-tRNA hydrolase as a facilitator of group II intron splicing in chloroplasts. EMBO J 20:872-879

Jenkins B, Kulhanek D, Barkan A (1997) Nuclear mutations that block group II RNA splicing in maize chloroplasts reveal several intron classes with distinct requirements for splicing factors. Plant Cell 9:283-296

Koussevitzky S, Stanne TM, Peto CA, Giap T, Sjögren LLE, Zhao Y, Clarke AK, Chory J (2007) An Arabidopsis thaliana virescent mutant reveals a role for ClpR1 in plastid development. Plant Mol Biol 63:85-96

Kusumi J, Tsumura Y, Yoshimaru H, Tachida H (2000) Phylogenetic relationships in Taxodiaceae and Cupressaceae based on matK, chlL, trnL-trnF IGS region and trnL intron sequences. Am J Bot 87:1480-1488

Landau A, Paleo AD, Civitillo R, Jaureguialzo M, Prina AR (2007) Two infA gene mutations independently originated from a mutator genotype in barley. J Hered 98:272-276

Leon P, Arroyo A, Mackenzie S (1998) Nuclear control of plastid and mitochondrial development in higher plants. Ann Rev Plant Physiol Plant Mol Biol 49:453-480

López-Juez E, Jarvis RP, Takeuchi A, Page AM, Chory J (1998) New Arabidopsis cue mutants suggest a close connection between plastid and phytochrome regulation of nuclear gene expression. Plant Physiol 118:803-815

Mohr G, Perlman PS, Lambowitz AM (1993) Evolutionary relationships among group II intron-encoded proteins and identification of a conserved domain that may be related to maturase function. Nucleic Acids Res 21:4991-4997

Neuhaus H, Link G (1987) The chloroplast tRNALys (UUU) gene from mustard (Sinapsis alba) contains a class II intron potentially coding for a maturase-related polypeptide. Curr Genet 11:251257

Nicholas KB, Nicholas HBJ, Deerfield DWI (1997) Gene-Doc: analysis and visualization of genetic variation. EMBNEW NEWS $4: 14$

Nimzyk R, Schöndorf T, Hachtel W (1993) In-frame length mutations associated with short tandem repeats are located in unassigned open reading frames of Oenothera chloroplast DNA. Curr Genet 23:265-270

Ohba K, Iwakawa M, Okada Y, Murai M (1971) Paternal transmission of a plastid anomaly in some reciprocal crosses of Sugi, Cryptomeria japonica D. Don. Silvae Genet 20:102-107

Ostersetzer O, Cooke AM, Watkins KP, Barkan A (2005) CRS1, a chloroplast group II intron splicing factor, promotes intron fold- 
ing through specific interactions with two intron domains. Plant Cell 17:241-255

Ostheimer G, Williams-Carrier R, Belcher S, Osborne E, Gierke J, Barkan A (2003) Group II intron splicing factors derived by diversification of an ancient RNA binding module. EMBO J 22:3919-3929

Rios RD, Saione H, Robredo C, Acevedo A, Colombo N, Prina AR (2003) Isolation and molecular characterization of atrazine tolerant barley mutants. Theor Appl Genet 106:696-702

Schmitz-Linneweber C, Barkan A (2007) RNA splicing and RNA editing in chloroplasts. In: Cell and molecular biology of plastid. Springer, Berlin, pp 213-248

Shaw J, Lickey EB, Beck JT, Farmer SB, Liu W, Miller J, Siripun KC, Winder CT, Schilling EE, Small RL (2005) The tortoise and the hare II: relative utility of 21 noncoding chloroplast DNA sequences for phylogenetic analysis. Am J Bot 92:142-166

Shiraishi S, Watanabe A (1995) Identification of chloroplast genome between Pinus densiflora $\mathrm{S}_{\mathrm{IEB}}$. et Zucc. And P. thunbergia $\mathrm{P}_{\mathrm{ARL}}$.
Based on the polymorphism in $r b c \mathrm{~L}$ gene (in Japanese). J Jpn For Sor 77:429-436

Till B, Schmitz-Linneweber C, Williams-Carrier R, Barkan A (2001) CRS1 is novel group II intron splicing factor that was derived from a domain of ancient origin. RNA 7:1227-1238

Vinti G, Fourrier N, Bowyer JR, López-Juez E (2005) Arabidopsis cue mutants with defective plastids are impaired primarily in the photocontrol of expression of photosynthesis-associated nuclear genes. Plant Mol Biol 57:343-357

Vogel J, Hübschmann T, Börner T, Hess WR (1997) Splicing and intron-internal RNA editing of trnK-matK transcripts in barley plastids: support for MatK as an essential splice factor. J Mol Biol 270:179-187

Vogel J, Börner T, Hess WR (1999) Comparative analysis of splicing of the complete set of chloroplast group II introns in three higher plant mutants. Nucleic Acids Res 27:3866-3874

Wyman SK, Jansen RK, Boore JL (2004) Automatic annotation of organellar genomes with DOGMA. Bioinformatics 20:3252-3255 